\title{
BIBLIOGRAPHIE / BIBLIOGRAPHY
}

Die nachfolgende Literaturauswahl ist erstellt in Zusammenarbeit mit der Übersee-Dokumentation des Deutschen Übersee-Instituts Hamburg.*

The following selected Bibliography has been compiled in cooperation with the Overseas Documentation of the German Overseas Institute, Hamburg. ${ }^{* *}$

\section{RECHT UND ENTWICKLUNG ALLGEMEIN / LAW AND DEVELOPMENT IN GENERAL}

Amelung, Thorsten / Diehl, Markus, Deforestation of Tropical Rain Forest. Nomos Verlagsgesellschaft, Baden-Baden, 1991.- 192 S. (= Kieler Studien 241) ISBN 3-16-145918-0.

Bieber, Roland, Das Verfahrensrecht von Verfassungsorganen. Ein Beitrag zur Theorie der inner- und interorganschaftlichen Rechtsetzung in der Europäischen Gemeinschaft, im Staatsrecht und Völkerrecht. Nomos Verlagsgesellschaft, Baden-Baden, 1992.- 396 S., ISBN 3-7890-1878-3.

Chowdhury, Subrata Roy / Denters, Erik M. G. I de Waart, Paul J. I. M. (eds.), The Right to Development in Intemational Law. Martinus Nijhoff Publishers, Dordrecht, June 1992.- 432 pp., ISBN 07923-1682-7.

Hohmann, Harald, Präventive Rechtspflichten und -prinzipien des modernen Umweltvölkerrechts. Zum Stand des Umweltvölkerrechts zwischen Umweltnutzung und Umweltschutz. Duncker \& Humblot, Berlin, 1992.- 439 S., ISBN 3-428-07410-6.

Hurwitz, Bruce A., State Liability for Outer Space Activities in Accordance with the 1972 Convention on International Liability for Damage Caused by Space Objects. Martinus Nijhoff Publishers, Dordrecht / NISER, June 1992.- 264 pp., ISBN 0-7923-1463-8.

Moshi, Humphrey P. B., Zum Entwicklungsbeitrag staatlicher Untemehmen in den Entwicklungsländem. Dargestellt am Beispiel Tansania. Nomos Verlagsgesellschaft, Baden-Baden, 1992.- 282 S. (= Schriften zur öffentlichen Verwaltung und öffentlichen Wirtschaft, Bd. 74), ISBN 3-7890-2547$\mathrm{X}$.

* Diese Bibliographie dient ausschließlich der Information. Die angegebenen Titel können von VRÜ und der Übersee-Dokumentation nicht geliefert werden.

** This Bibliography serves information purposes only. Neither VRÜ nor the Overseas documentation can supply any of the titles listed. 
United Nations Office at Vienna Centre for Social Development and Humanitarian Affairs (ed.), Women in Politics and Decision-Making in the Late Twentieth Century. A United Nations Study. Martinus Nijhoff Publishers, Dordrecht / United Nations, June 1992.- 140 pp., ISBN 0-7923-16487.

Weimer, Bernhard, Das Ende der weißen Vorherrschaft im südlichen Afrika. Die Wirtschaftskrise in Südafrika und ihre Auswirkungen auf die Beziehungen zu den Nachbarstaaten. Nomos Verlagsgesellschaft, Baden-Baden, 1992.- 380 S., ISBN 3-7890-2598-4.

\section{AFRIKA / AFRICA}

Allouche, Bousetta, Small states and international mediation. The case of Algeria. Office des Publications Universitaires, Alger, 1989.- 452 S.

Bourgi, Albert, Ouverture démocratique à la sénégalaise, in: Jeune Afrique (Paris). 31 (17 avril 1991) 1581, S. 20-24.

Brehme, Gerhard, Die Verfassung des unabhängigen Namibia, in: Asien, Afrika, Lateinamerika (Berlin). 19 (1991) 1, S. 110-120.

Coldham, Simon, Customary marriage and the urban local courts in Zambia, in: Joumal of African Law (London). 34 (Spring 1990) 1, S. 67-75.

DuPlessis, A., Just war doctrine. Developments, ramifications and its relevancy in the South African context, in: Strategic Review for Southem Africa (Pretoria). 12 (May 1990) 1, S. 14-50.

Fisiy, Cyprian Fonyuy, Le monopole juridictionnel de l'Etat et le règlement des affaires de sorcellerie au Cameroun, in: Politique africaine (Paris). (décembre 1990) 40, S. 60-71.

Fourie, F. C. v. N., The Namibian constitution and economic rights, in: South African Joumal on Human Rights (Johannesburg). 6 (1990) 3, S. 363-371.

Gabon. Une démocratisation réussie?, in: Jeune Afrique (Paris). 31 (6 mars 1991) 1575, S. 37-67.

Kuder, Manfred (Hrsg.), Die Verfassung der Republik Moçambique vom 30.11.1990, Übersetzung und Kommentar von Brigitte Camurca; Erläuterungen von Reinhold Schattenfroh. Deutsche Gesellschaft für die afrikanischen Staaten portugiesischer Sprache, Bonn, 199.- 102 S. (= DASP-Jahrbuch 1991, Bd. 1).

Lingle, Christopher, Constitutional political economy and analysis of reform altematives for postapartheid South Africa, in: Studies in Economics and Econometrics (Stellenbosch). 15 (1991) 1, S. 31-41.

Ngwasiri, C.N., The effect of legislation on foreign investment. The case of Cameroon, in: Journal of African Law (London). 33 (Autumn 1989) 2, S. 192-204.

Ojwang, J. B., The legal profession in Kenya, in: Journal of African Law (London). 34 (Spring 1990) 1, S. 9-26.

Robertson, Michael, Land and human rights in South Africa. A reply to Markus and Skweyiya, in: South African Joumal on Human Rights (Johannesburg). 6 (1990) 2, S. 215-227.

Saint Moulin, Leon de, Brève histoire des constitutions du Zaïre, in: Zaïre-Afrique (Kinshasa). (juinjuillet 1991) 256, S. 291-316. 
Sholanke, Oladipo $O$., Is the grant of govemor's consent under the Nigerian land use act automatic?, in: Joumal of African Law (London). 34 (Spring 1990) 1, S. 42-52.

Skweyiya, Zola, Towards a solution to the land question in post-apartheid South Africa. Problems and Models, 1990

Waterbury, John, Legal and institutional arrangements for managing water resources in the Nile Basin, in: Simon, Reeva S. (ed.), The Middle East and North Africa: essays in honor of J. C. Hurewitz. Columbia University Press, New York/N.Y., 1990, S. 276-303, ISBN 0-231-07148-5.

\section{ASIEN / ASIA}

Bayles, Deborah L., The reunification of China. An examination of the legal systems of the People's Republic of China, Hong Kong, and Taiwan, in: The Denver Joumal of Intemational Law and Policy (Denver/Col.). 19 (1991) 2, S. 443-466.

Bestimmungen des Staatsrats der Volksrepublik China über den Verwaltungswiderspruch, in: China aktuell (Hamburg). 20 (Juni 1991), S. 378-385.

Case, William, Comparative Malaysian leadership: Tunku Abdul Rahman and Mahathir Mohamad, in: Asian Survey (Berkeley/Cal.). 31 (May 1991) 5, S. 456-473.

Cheever, Gene, Australian intemational bankruptcy law, in: Joumal of Intemational Business Law (Amsterdam). 12 (1990) 1, S. 153-171.

Chen Xiaomin, Regulation of foreign banking in the People's Republic of China, in: Butterworth's Joumal of Intemational Banking and Financial Law (London). 5 (1990) 6, S. 253-259.

Cheng Jianying, Das Konkursrecht der Volksrepublik China, in: Zeitschrift für vergleichende Rechtswissenschaft (Heidelberg). 90 (1991) 1, S. 47-79.

Chin Kin Wah, The five power defence arrangements. Twenty years after, in: The Pacific Review (Oxford). 4 (1991) 3, S. 193-203.

Chuang, Richard $Y$. The joint declaration on Hong Kong and Macao and the draft basic law for Hong Kong, in: Revue de droit international de sciences diplomatiques et politiques (Genève). (AprilJune 1990) 2, S. 139-152.

Clark, Janet, Singapore, in: Intemational Tourism Report (London). (1990) 2, S. 68-91 .

Clarke, W. S., The Privy Council, politics and precedent in the Asia-Pacific region, in: The International and Comparative Law Quarterly (London). 39 (October 1990) 4, S. 741-756.

Davis, Michael C., Constitutional confrontation in Hong Kong. Macmillan, London, 1990, 219 S., ISBN 0-333-49452-0.

Dietz, Adolf, Zum neuen Urheberrechtsgesetz der Volksrepublik China. Eine Einführung, in: Gewerblicher Rechtsschutz und Urheberrecht: Intemationaler Teil (Weinheim/Bergstr.). (1990) 12, S. 905 912.

Fouquoire-Brillet, Elisabeth, Les Kouriles. Un contentieux insulaire majeur en Extreme-Orient, in: Stratégique (Paris). (2. trimestre 1991) 50, S. 191-202.

Ginsburgs, George, The territorial question between the USSR and Japan. The Soviet case and a westem aperçu, in: Korea and world Affairs (Seoul). 15 (Summer 1991) 2, S. 259-278. 
Hebel, Jutta / Schucher, Günter, Das Arbeitsvertragssystem in der VR China. Ein Beitrag zur Verrechtlichung der Abeitsbeziehungen?, in: Osteuropa-Recht (Stuttgart). 36 (März 1990) 1, S. 5372.

Herzog, Jürgen, Historischer Prozeß und Unterentwicklung in Asien und Afrika. Forderungen an den Historiker und wie er sich ihnen stellen kann, in: Asien, Afrika, Lateinamerika (Berlin). 18 (1990) 4, S. 585-598.

HoSzu-yin, The dynamics of political competition in the Republic of China on Taiwan. A game-theoretical analysis, in: Issues and Studies (Taipei). 27 (July 1991) 7, S. 97-111.

Hours, Bernard, Islam et politique au Bangladech, in: Revue tiers-monde (Paris). 31 (juillet-septembre) 123, S. 693-701.

Hüttermann, Armin, Bikulturalismus nach 150 Jahren weißer Vorherrschaft? Maori in Neuseeland, in: Geographische Rundschau (Braunschweig). 42 (1990) 3, S. 126-134.

Jessen, Brigitte, Armutsorientierte Entwicklungshilfe in Bangladesch. Hilfe oder Hindernis für die Entwicklung? Verlag für Wissenschaft und Kunst, Berlin, 1990.- 280 S., ISBN 3-927408-38-7.

Keith, Ronald C., Chinese politics and the new theory of "rule of law", in: The China Quarterly (London). (March 1991) 125, S. 109-118.

Kim Hakjoon, Korean reunification. A Seoul perspective, in: Korea and World Affairs (Seoul). 15 (Spring 1991) 1, S. 5-20.

Kosambi, Meera, Girl-brides and socio-legal change. Age of Consent Bill (1891) controversy, in: Economic and Political Weekly (Bombay). 26 (August 3-10, 1991) 31-32, S. 1857-1868.

Kowalewski, David, Vigilante conterinsurgeny and human rights in the Philippines. A statistical analysis, in: Human Rights Quarterly (New York/N.Y.). 12 (1990) 2, S. 246-264.

Kunig, Philip, Kolonisierung nach der Entkolonisierung? Zur Beendigung der UN-Treuhandschaft über Mikronesien, die Marshallinseln und die Nördlichen Marianen, in: Vereinte Nationen (Kehl). 39 (April 1991) 2, S. 55-60.

Küppens, Kon, What is to be done with the four islands?, in: Far Eastem Affairs (Moscow). (1991) 3, S. 90-93.

Lambertson, Davod Floyd, Political situation in Burma, in: Department of State Bulletin (Washington/ D.C.). (December 1989) 2153, S. 37-38.

Liao, Hollis S., Recent political reform in Mongolia, in: Issues and Studies (Taipei). 27 (June 1991) 6, S. 86-101.

Liu Jen-Kai, Ausgewählte Regierungspublikationen der U.S.A. zu Politik, Wirtschaft und Gesellschaft Asiens von 1972 - 1984. Institut für Asienkunde und Referate Asien und Südpazifik der ÜberseeDokumentation, Deutsches Übersee-Institut, Hamburg, 1990.- 150 S., ISBN 3-922852-33-5.

Löschmann, Heike, Buddhismus und gesellschaftliche Entwicklung in Kambodscha seit der Niederschlagung des Pol-Pot-Regimes im Jahre 1979, in: Asien (Hamburg). (Juli 1991) 40, S. 13-27.

Matsushita, Mutsuo, The role of competition law and policy in reducing trade barriers in Japan, in: The World Economy (Oxford). 14 (June 1991) 2, S. 181-197.

Meier, Frank, Zum gegenwärtigen Stand der Wirtschaftsreformen in Vietnam. BOIS, Köln, 1991.- 8 S. (= Aktuelle Analysen / Bundesinstitut für Ostwissenschaftliche und Intemationale Studien, Nr. 25/1991). 
Menzel, Ulrich (Hrsg.), Nachdenken über China. Suhrkamp, Frankfur/Main, 1990.- 289 S. (= Edition Suhrkamp, 1602: Neue Folge, Bd. 602).

Mo, John S., Some aspects of the Australia-China Investment Protection Treaty, in: Joumal of World Trade (Genevy). 25 (June 1991) 3, S. 43-80.

Mushkat, Miron, The political economy of constitutional change in Hong Kong, in: Asian Economies (Seoul). (December 1990) 75, S. 33-53.

Nieh Yu-hsi, Die Verfassungskrise in Taiwan, in: China aktuell (Hamburg). 20 (Mai 1991), S. 296-299.

Nunn, P. D., Recent environmental changes on Pacific islands, in: The Geographical Joumal (London). 156 (July 1990) 2, S. 125-140.

Pabottingi, Mochtar, How language determined Indonesian nationalism, in: Prisma (Jakarta). (September 1990) 50, S. 7-24.

Pascha, Werner, Dritte Welt im Aufbruch. Ostasiatische Schwellenländer als neue weltwirtschaf liche Entwicklungspole?, in: Cassel, Dieter (Hrsg.), Wirtschaftssysteme im Umbruch. Sowjetunion, China und industrialisierte Marktwirtschaften zwischen intermationalem Anpassungszwang und nationalem Reformbedarf. Vahlen, München, 1990, S. 92-120, ISBN 3-8006-1453-7.

Prohl, Werner M., Die Kommunalwahlen in Sri Lanka am 11. Mai 1991, in: KAS-Auslandsinformationen (Sankt Augustin). 7 (Juni 1991) 6, S. 29-31.

Rechtsgrundlagen zu r außergerichtlichen Streitbeilegung in der Volksrepublik China, in: China aktuell (Hamburg). 20 (Juni 1991), S. 386-392.

Sangwan, Sunanda, The European Community and the non-associated countries. The trade agreement between the EEC and India, in: Joumal of World Trade (Geneva). 25 (June 1991) 3, S. 33-42.

Sanwal, Mukul, End user in development administration. The vital role of administrators, in: Public Administration and Development (Chichester). 10 (1990) 2, S. 221-232.

Siemers, Günter, Mongolei: vom Kornmunismus zur Demokratie und Marktwirtschaft?, in: Asien (Hamburg). (Juli 1991) 40, S. 28-49.

Späth, Manfred, Südliche Kurilen - nördliche Territorien. Der Inselkonflikt vor Gorbatschows Staatsbesuch in Japan. BOIS, Köln, 1991.- 8 S. (= Aktuelle Analysen / Bundesinstitut für Ostwissenschaftliche und Internationale Studien, Nr. 17/1991).

Stucken, Bernd Uwe, Chinesisches Außenwirtschaftsrecht, in: Der Betriebswirt (Gernsbach). 31 (1990) 1, S. 22-28.

Tao Dehai, China and services negotiations, in: Joumal of World Trade (Geneva). 25 (April 1991) 2, S. 23-54.

Thapa, Gopal B., Actors and factors of deforestation in "Tropical Asia", in: Environmental Conservation. 17 (1990) 1, S. 19-27.

The tropical forestry action plan. Regional priorities for Asia and Pacific, in: Unasylva (Rome). 41 (1990) 162, S. 49-63.

Tiglao, T., The Philippine paradox. Despite the political crises, the economy thrives, in: Far Eastem Economic Review (Hongkong). 149 (July 12, 1990) 28, S. 31-46.

Wang Chien-hsün, Peking's Latin America policy in the 1980's, in: Issues and Studies (Taipei). 27 (May 1991) 5, S. 103-118. 
Weggel, Oskar, Asiens politische und sozioökonomische Entwicklungen seit 1945, in: Pleticha, Heinrich (Hrsg.), Weltgeschichte: Krise und Fortschrift. Die modeme Welt. Bertelsmann Lexikon Verlag, Gütersloh, 1990, S. 133-174, ISBN 3-570-09662-9.

Weggel, Oskar, Demokratisierung und regionaler Wandel in Ost- und Südostasien, in: Die internationale Politik 1987 - 1988, Forschungsinstitut der Deutschen Gesellschaft für Auswärtige Politik. Oldenbourg, München, 1990, S. 305-322, ISBN 3-486-55842-0.

Weggel, Oskar, Konturen einer neuen Außenpolitik Vietnams, in: Südostasien aktuell (Hamburg). 10 (Mai 1991) 3, S. 243-271.

Weggel, Oskar, Tibetische Vorwürfe: und wie China dagegenhält, in: China aktuell (Hamburg). 20 (Juni 1991), S. 374-377.

Weggel, Oskar, Zum 40. Jahrestag der Befreiung Tibets. Wie China seine Souveränitätsansprüche über die "Autonome Region" zu rechtfertigen versucht, in: China aktuell (Hamburg). 20 (Juni 1991), S. 361-373.

Wignaraja, Ganeshan, Industrialisation and social development. Comparisons of South Asia with East Asian NICs, in: Marga (Colombo). 11 (1990) 1, S. 48-83.

Wohlgemuth, Arno, Neueste Entwicklungen im vietnamesischen Recht der Auslandsinvestitionen, in: Verfassung und Recht in Ubersee (Baden-Baden). 24 (3. Quartal 1991) 3, S. 282-287.

Yon-Ju Jung, Das deutsche und das koreanische Enteignungsinstitut. Verlag V. Florentz, München, 1991.- 281 S., ISBN 3-88259-784-4.

\section{VORDERER ORIENT / NEAR AND MIDDLE EAST}

Amoretti, Biancamaria Scarcia, Die historische Entwicklung der Sekten im Islam, in: Der Islam (3). Islamische Kultur - zeitgenössische Strömungen - Volksfrömmigkeit. Kohlhammer, Stuttgart, 1990, S. 100-156 (Die Religionen der Menschheit; 25,3), ISBN 3-17-010061-0.

Antes, Peter, Der Islam als politischer Faktor. Bundeszentrale für Politische Bildung, Bonn, 1991.- 99 $\mathrm{S}$.

Bund, Susanne, Golfkrieg. Zeitschriftenauswahlbibliographie 1991, in: S und F: Vierteljahresschrift für Sicherheit und Frieden (Baden-Baden). 9 (1991) 3, S. 163-165.

Burrowes, Robert D., Prelude to unification. The Yemen Arab Republic, 1962 - 1990, in: International Journal of Middle East Studies (New York/N.Y.). 23 (November 1991) 4, S. 483-506.

Chehabi, Houchang Esfandiar, Religion and politics in Iran. How theocratic is the islamic republic?, in: Daedalus (Cambridge/Mass.). 120 (Summer 1991) 3, S. 69-92.

Der Nahe Osten, in: Das Parlament (Bonn). 41 (6.-13. September 1991) 37-38, S. 1-24.

Evans, John B., OPEC and the world energy market. A comprehensive reference guide. Longman, Harlow, 1991.- 749 S., ISBN 0-582-08527-6.

Faath, Sigrid (Hrsg.), Demokratie und Menschenrechte in Nordafrika. Ed. Wuquf, Hamburg, 1991.563 S., ISBN 3-924577-09-9. 
Faath, Sigrid, Anspruch und Grenzen der Demokratisierungsbestrebungen in Tunesien unter Präsident Ben Ali, in: Faath, Sigrid (Hrsg.), Demokratie und Menschenrechte in Nordafrika. Ed. Wuquf, Hamburg, 1991, S. 487-563, ISBN 3-924577-09-9.

Faath, Sigrid, Der Demokratisierungsimpuls der algerischen Verfassung von 1989, in: Faath, Sigrid (Hrsg.), Demokratie und Menschenrechte in Nordafrika. Ed. Wuquf, Hamburg, 1991, S. 229-288, ISBN 3-924577-09-9.

Farag, Iman, La politique à l'égyptienne. Lecture des élections législatives, in: Monde arabe: Maghreb - Machrek (Paris). (juillet-septembre 1991) 133, S. 19-33.

Gebhardt, Marion, Institutionen der gegenwartsbezogenen Orientforschung und -information in der Bundesrepublik Deutschland und Berlin (West) (Stand 1990). Forschungsinstitute, Bibliotheken, Dokumentationsstellen und Archive (= Dokumentationsdienst Vorderer Orient: Reihe B; 2), ISBN 3-922852-39-4.

Golan, Galia, Soviet policies in the Middle East. From World War two to Gorbachev. Cambridge University Press, Cambridge/Mass., 1990.- 319 S.

Hanf, Theodor, Koexistenz im Krieg. Staatszerfall und Entstehen einer Nation im Libanon. Nomos Verlagsgesellschaft, Baden-Baden, 1990.- 827 S. (= Schriften des Forschungsinstituts der Deutschen Gesellschaft für Auswärtige Politik e.V., Bonn), ISBN 3-7890-1972-0.

Karner, Gerald, Die Friedenstruppe der Vereinten Nationen zur Überwachung des Waffenstillstandes zwischen Irak und Kuwait (UNIKOM), in: Österreichische militärische Zeitschrift (Wien). (November/Dezember 1991) 6, S. 534-537.

Khoury, Adel Theodor, Was ist los in der islamischen Welt? Die Konflikte verstehen. Herder, Freiburg/ Br., 1991.- 155 S., ISBN 3-451-22397-X.

Khoury, Philip S. / Kostiner, Joseph (eds.), Tribes and state formation in the Middle East. Tauris, London, 1991.- $351 \mathrm{~S}$.

Kretzmer, David, The legal status of the Arabs in Israel. Westview Press, Boulder/Colo., 1990.- 197 S. (= Westview Special Studies on the Middle East), ISBN 0-8133-7762-5.

Kurden: Kämpfe und Konflikte um Kurdistan. Comelsen und Schroedel, Berlin, 1991.- 16 S.

Landmann, Kamillo, Die Geschichte des vierzigjährigen Krieges in Nahost. Herchen, Frankfurt/ Main, 1991.- 136 S., ISBN 3-89184-096-9.

Lewis, Bernard, Die politische Sprache des Islam. Rotbuch Verlag, Berlin, 1991.- 257 S. (= Rotbuch Rotationen).

Maddy-Weitzmann, Bruce, Conflict and conflict management in the Westem Sahara. Is the endgame near?, in: The Middle East Journal (Washington/D.C.). 45 (Autumn 1991) 4, S. 594-607.

Mattes, Hanspeter, Modeme arabische Verf assungsentwicklung, in: Faath, Sigrid (Hrsg.), Demokratie und Menschenrechte in Nordafrika. Ed. Wuquf, Hamburg, 1991, S. 49-72, ISBN 3-924577-09-0.

Mayer, Ann Elizabeth, Islam and human rights. Tradition and politics. Westview Press, Boulder/Colo., 1991.- 258 S., ISBN 0-8133-8091-X.

Menashri, David (ed.), The Iranian revolution and the Muslim world. Moshe Dayan Center for Middle Eastem and African Studies. Westview Press, Boulder/Colo., 1990.- 282 S. (= Westview Special Studies on the Middle East). 
Mernissi, Fatime el-, Women and Islam. An historical and theological enquiry. Blackwell, Oxford, 1991.- 228 S., ISBN 0-631-16904-0.

Mortimer, Robert A., Islam and multiparty politics in Algeria, in: The Middle East Joumal (Washington/D.C.). 45 (Autumn 1991) 4, S. 575-593.

Orient: Zwischenstaatliche Organisationen und Wiedervereinigung des Jemen, in: Jahrbuch Dritte Welt 1991 / Hrsg. vom Deutschen Úbersee-Institut. Beck, München, 1990, S. 244-251 (Beck'sche Reihe 417), ISBN 3-406-34009-1.

Richova, Blanka, The ethnic conflict as the factor of state coherency in Africa. The case of Sudan, in: Archiv orientalni (Praha). 59 (1991) 3, S. 289-312.

Robins, Philip J., Turkey and the Middle East. Pinter, London, 1991.- 130 S.

Rudolph, Ekkehard, Westliche Islamwissenschaft im Spiegel muslimischer Kritik. Grundzüge und aktuelle Merkmale einer innerislamischen Diskussion. Schwarz, Berlin, 1991.- 217 S. (= Islamkundliche Untersuchungen 137), ISBN 3-922968-79-1.

Ruf, Werner Klaus, Die Hintergründe des Krieges. Schlaglichter auf die Geschichte des Nahen Ostens, in: Ruf, Werner (Hrsg.), Vom Kalten Krieg zur heißen Ordnung? Lit Verlag, Münster, 1991, S. 148 (Intemationale Politik und intergesellschaftliche Beziehungen, Bd. 1).

Sanders, Wilm (Hrsg.), Die Christen im Libanon. Katholische Akademie, Hamburg, 1990.- 176 S. (= Publikationen der Katholischen Akademie Hamburg 9).

Schachter, Oskar, United Nations law in the Gulf conflict, in: American Joumal of International Law (Washington/D.C.). 85 (July 1991) 3, S. 452-473.

Scheffler, Thomes (Hrsg.), Ethnizität und Gewalt. Deutsches Orient-Institut, Hamburg, 1991.

Schmidt, Renate, Zu einigen Aspekten der Vereinigung beider jemenitischer Staaten, in: Asien, Afrika, Lateinamerika (Berlin). 19 (1991) 2, S. 293-304.

Slater, Jerome, A Palestinian state and Israeli security, in: Political Science Quarterly (New York/N.Y.). 106 (Fall 1991) 3, S. 411-429.

Stein, Georg (Hrsg.), Nachgedanken zum Golfkrieg. Palmyra, Heidelberg, 1991.- 300 S.

Tibi, Bassam, Die Krise des modemen Islams. Eine vorindustrielle Kultur im wissenschaftlich-technischen Zeitalter. Suhrkamp, Frankfur/Main, 1991.- 314 S. (= Suhrkamp Taschenbuch Wissenschaft 889), ISBN 3-518-28489-4.

Türkei-Sozialkunde. Wirtschaft, Beruf, Bildung, Religion, Familie, Erziehung. Zentrum für Türkeistudien (Hrsg.), Leske und Budrich, Opladen, 1991.- $160 \mathrm{~S}$. (= Schriftenreihe des Zentrums für Türkeistudien 9).

Walther, Wiebke, Die Frau im Islam, in: Der Islam (3). Islamische Kultur - zeitgenössische Strömungen - Volksf römmigkeit. Kohlhammer, Stuttgart, 1990, S. 388-414 (Die Religionen der Menschheit; 25,3), ISBN 3-17-010061-0.

Wedel, Heidi, Der türkische Weg zwischen Laizismus und Islam. Zur Entwicklung des Laizismusverständnisses in der türkischen Republik. Leske und Budrich, Opladen, 1991.- 141 S. (= Studien und Arbeiten des Zentrums für Türkeistudien, Bd. 6), ISBN 3-8100-0854-0.

Wolffsohn, Michael, Der Nahe Osten im Spannungsfeld von Nationalität, Territorialität und staatlicher Identität, in: Haungs, Peter (Hrsg.), Politik ohne Vertrauen? Nomos Verlagsgesellschaft, Baden- 
Baden, 1990, S. 105-128 (Veröffentlichungen der Deutschen Gesellschaft für Politikwissenschaft, Bd. 8), ISBN 3-7890-2158-X.

Wright, Robin, In the name of God. The Khomeini decade. Bloomsbury, London, 1991.- 284 S., ISBN 07475-0963-8.

Zartmann, William I. (ed.), Tunisia: the political economy of reform. Rienner, Boulder/Colo., 1991.267 S. (= SAIS African Studies Library).

\section{LATEINAMERIKA / LATIN AMERICA}

Birle, Peter, Vom "Plan Bunge \& Bom" zum Plan "Cavallo". Argentiniens wirtschaftliche und politische Situation nach zwei Jahren peronistischer Regierung. Deutsches Übersee-Institut, Hamburg, 1991.- 48 S., ISSN 0178-8825.

Ensignia, Jaime / Nolte, Detlef (Hrsg.), Modellfall Chile? Ein Jahr nach dem demokratischen Neuanfang. Deutsches Übersee-Institut, Hamburg, 1991.- 210 S., ISBN 3-926446-12-9.

Gleich, Albrecht von / Kohlhepp, Gerd / Mols, Manfred (Hrsg.), Neue Konzepte in der Entwicklungszusammenarbeit mit Lateinamerika? Ein Dialog zwischen Entwicklungspolitik und Wissenschaft. Deutsches Übersee-Institut, Hamburg, 1991.- 150 S., ISBN 3-926446-11-0.

Krempin, Michael, Krise als Chance? Neoliberale Wirtschaftspolitik und Gewerkschaftsbewegung in Bolivien. Deutsches Übersee-Institut, Hamburg, 1991.- 77 S., ISBN 3-926446-08-0.

Meyer, Michael C. / Sherman, William L., The course of Mexican history. 1991.- 800 S.

Nohlen, Dieter / Nuscheler, Franz (Hrsg.), Handbuch der Dritten Welt. Band 2: Südamerika.- ca. 460 S., ISBN 3-8012-0182-1.

Nohlen, Dieter / Nuscheler, Franz (Hrsg.), Handbuch der Dritten Welt. Band 3: Mittelamerika und Karibik.- ca. 460 S., ISBN 3-8012-0183-X.

Nolte, Detlef, Lateinamerika im Umbruch? Wirtschaftliche und politische Veränderungen an der Wende von den 80er zu den 90er Jahren. Deutsches Übersee-Institut, Hamburg, 1991.- 292 S., ISBN 3-926446-10-2.

Nolte, Detlef, Menschenrechte in Chile. Ist die Politik der Aussöhnung gescheitert? Deutsches ÜberseeInstitut, Hamburg, 1991.- 48 S., ISSN 0178-8825.

Porst, Gunter, Investitionsland Brasilien. Rahmenbedingungen, Wirtschaftsrecht und Wirtschaftspraxis. Deutsches Übersee-Institut, Hamburg, 1991.- 157 S., ISBN 3-926446-09-9.

Richardson, Bonham C., The Caribbean in the wider world, 1492 - 1992. (Geography of the WorldEconomy). 1992.- $256 \mathrm{~S}$.

Tichy, Franz, Die geordnete Welt indianischer Völker (El mundo ordenado de los Pueblos Indios). Ein Beispiel von Raumordnung und zeitordnung im vorkolumbianischen Mexiko. (Das Mexiko-Projekt der Deutschen Forschungsgemeinschaft, 21). 1991.- ca. 220 S. 